\title{
KASUS PENYEBARAN HOAKS DI INDONESIA DALAM SUDUT PANDANG FILSAFAT MANUSIA
}

\author{
Oleh: \\ Andika Aditian Afanda \\ Universitas Widya Mandala Madiun \\ andika.aditian27@gmail.com
}

\begin{abstract}
ABSTRAK
Seiring dengan perkembangnya teknologi, kemudahan penyampaian informasi begitu cepat. Setiap orang dapat dengan mudah membuat, meyebar luaskan, serta menerima berbagai bentuk informasi. Dengan kemudahan mendapatkan informasi tersebut muncul juga berita hoaks didalamnya, yakni berita mengandung judul yang provokatif, mengadu domba, fitnah, membuka aib baik itu seseorang ataupun kelompok, serta menggiring opini untuk menyatakan suatu kelompok lebih unggul daripada yang lain. Berfilsafat merupakan proses berpikir untuk mencari suatu kebenaran. Maka hal itu kita harus berperilaku bijak dalam menanggapi suatu informasi yang tersebar dengan cara berpikir secara kritis dan membangun pertanyaan apakah suatu informasi itu benar ataupun salah, tujuan dan maksud informasi tersebut untuk apa.
\end{abstract}

Kata Kunci: Informasi, Hoaks, Filsafat

\section{PENDAHULUAN}

\subsection{Latar Belakang}

Perkembangan teknologi dewasa ini memberikan dampak dan pengaruh bagi kehidupan manusia, tidak hanya dampak positif yang ditimbulkan dari adanya perkembangan teknologi, namun juga dampak negatif. Kemudahan penyampaian 
informasi begitu cepat seiring dengan perkembangannya, banyak orang dengan mudah memproduksi informasi, dan menyebarkannya melalui banyak media online baik laman pencarian google, dan jejaring sosial seperti facebook, twiteer, dan sebagainya yang tidak dapat difilter dengan baik. Informasi yang telah dikirim dan dibaca banyak orang dapat mempengaruhi emosi, pikiran, dan tindakan seseorang. Hal ini juga termasuk jika informasi yang disebarkan merupakan informasi yang tidak akurat, berita bohong, dan terdapat judul yang provokatif dengan tujuan menggiring opini pembaca kearah yang negatif. Opini yang diterima membuat orang atau kelompok yang diberitakan merasa terancam, kemudian takut dan menimbulkan kerugian baik materil maupun non materil. Jumlah situs yang mengandung berita palsu/hoaks naik setiap bulannya sejak Agustus 2018 hingga April 2019.

Kominfo melalui Siaran Pers No. 95/HM/KOMINFO/05/2019 merilis tentang jumlah hoaks selama April 2019 sebanyak 486 serta total hoaks sejak Agustus 2018 hingga April 2019 sebanyak 1.731. Peningkatan jumlh konten hoaks sangat signifikan terjadi pada bulan Januari dan Februari, dimana pada bulan Januari jumlahnya sekitar 175 kemudian pada bulan Februari naik dua kali lipat sebanyak 353 konten hoaks. Berita hoaks juga semakin meningkat setiap bulannya seiring dengan semakin dekatnya proses pemilu di bulan April. Konteks berita hoaks yang disebarkan meliputi berbagai banyak hal, baik mulai isu keagamaan, politik, ekonomi, pemerintahan, kesehatan dan isu lainnya.

Dengan adanya hal demikian, maka kita harus bijak dalam menyikapi perkembangan teknologi saat ini, kita sebagai manusia harus mampu melihat sisi positif dalam setiap perkembangan teknologi terbarukan sehingga dapat memberikan manfaat baik untuk diri kita sendiri ataupun untuk orang yang ada disekitar kita. Dengan demikian nilai-nilai moral, kejujuran, dan manfaat bisa dirasakan untuk semua pihak, namun hal ini akan berbeda bagi manusia yang menyikapi suatu perkembangan teknologi dengan tidak bijak, melihat hoak sebagai kesempatan untuk kepentingan pribadi dengan menggunakan cara yang tidak dibenarkan serta merugikan berbagai pihak itulah yang mereka harapkan. 


\subsection{Rumusan Masalah}

1. Penyebaran hoax di dalam masyarakat

\subsection{Tujuan Masalah}

1. Memberikan pendapat guna mengubah pola pikir masyarakat sebagai pembuat dan penerima hoax.

\section{KAJIAN TEORI}

\section{Teknologi Informasi}

Pengertian teknologi secara umum adalah alat, mesin, cara, proses, kegiatan ataupun gagasan yang dibuat untuk mempermudah aktifitas manusia dalam kehidupan sehari hari.

Teknologi informasi ialah suatu bentuk teknologi yang dipergunakan dalam mengolah data, memproses, menyusun, menyimpan, serta mengubah sebagian atau keseluruhan data dengan berbagai cara guna mendapatkan informasi yang berkualitas, akurat, dan relevan, untuk kepentingan pribadi maupun kelompok. Menurut Lucas (2003) adalah segala bentuk teknologi yang dapat diterapkan untuk mengirimkan sebuah informasi melalui media elektronik.

Dengan adanya teknologi informasi memungkinkan sesama manusia mendapatkan berbagai hal atau pandangan untuk kebutuhan hidup, baik informasi kesehatan, pola hidup, ras, suku, agama, politik, dan masih banyak lagi hal lainnya yang didapat dari adanya teknologi informasi. Perkembangan teknologi menciptakan suatu cara baru dalam kehidupan yang dipengaruhi oleh kebutuhan elektronik.

\section{Hoax}

Hoax adalah kabar, informasi, berita palsu atau bohong. Didalam KBBI hoaks diartikan sebagai berita bohong. Sedangkan menurut wikipedia hoaks adalah 
informasi yang sesungguhnya tidak benar, namun dibuat seolah-olah benar adanya meskipun pembuat tahu bahwa berita tersebut tidak benar. Banyak hal yang melatarbelakangi adanya berita bohong yang menyebar luas di masyarakat, baik hanya untuk bercanda, hingga sampai penggiringan opini terhadap suatau hal yang memang mungkin masih menjadi tanda tanya akan kebenarannya. Hoaks biasa muncul di dalam media sosial karena tidak terdapat filter yang otomais menyaring berita bohong, sehingga berita apapun bisa tersebar dengan mudah dan dibaca oleh banyak orang.

\section{Filsafat Manusia}

Di dalam diktat filsafat manusia (2019:1) dijelaskan bahwa Filsafat manusia (filsafat antropologi) adalah filsafat integral dan mendalam tentang manusia. Tidak hanya secara biologis, psikologis. Filsafat manusia lebih bernuansa metafisis. Manusia adalah makhluk yang senantiasa berpikir, dengan kemampuan berpikir inilah manusia manusia memperoleh jawaban yang bersifat logis. Proses berfilsafat adalah proses berpikir, tetapi tidak semua proses berpikir adalah berfilsafat. Berfilsafat adalah proses berpikir yang radikal, logis, universal, konseptual, koheren, konsisten, sistematik, komperenhensif, kritis, bebas, bertanggung jawab, dan bijaksana. Filsafat ditujukan untuk mendapatkan kebenaran mutlak yaitu benar dilihat dari berbagai sudut pandang dan benar pula untuk sepanjang masa.

Filsafat membantu manusia untuk mencari kebenaran dari segala fenomena yang ada, memberikan pengertian tentang cara hidup, pandangan hidup dan pandangan dunia, memberikan ajaran tentang moral dan etika yang berguna dalam kehidupan memahami diri sendiri dan dunia, mengembangkan kemampuan dalam menalar, dan memberikan bekal untuk memperhatikan pandangan diri sendiri dan orang lain dengan kritis. Fakta yang terdapat dalam diri manusia: manusia dapat berpikir dan bertanya, juga tentang dirinya sendiri. Penggalian historis dan bahasa menunjukan bahwa di dalamnya ada arti yang agung sekaligus yang hina. Kata "Manusia" secara etimologi berasal dari bahasa sansekerta: manusya. Bahasa Inggris human, dari kata lain homo, yang berasal dari kata humus (tanah). Dari situ maka kita tidak boleh terlalu mengagungkan dan terlalu merendahkan manusia. Dalam pendekatan manusia menggunakan ilmu biologi, manusia merupakan bagian 
dari makhluk hidup, sehingga manusia tergolong sebagai binatang menyusui tertinggi (melebihi kera). Dari pendekatan tersebut manusia justru disamakan dengan binatang, karena tidak terdapat perbedaan. Namun apakah hakekatnya manusia seperti demikian. Beberapa filosof meberikan pendapatnya sebagai beriku diantaranya menurut Max Scheler: Manusia terdiri dari tubuh dan roh. Kekhasan manusia untuk mengatakan "tidak" pada dorongan naluriah. Kemampuan itu adalah kemampuan roh yang keberadaannya terserap dalam seluruh diri manusia. Scheler berpendapat bahwa rasa malu adalah batas diantara manusia dengan binatang.

\section{PEMBAHASAN}

Kemajuan teknologi saat ini sudah seperti menjadi budaya didalam kehidupan bermasyarakat di Indonesia, teknologi dipergunakan diberbagai kebutuhan hidup manusia, seperti halnya kebutuhan komunikasi bagi manusia. Dengan adanya handphone semakin mempermudah komunikasi antara manusia, dimanapun tempatnya dan kapanpun waktunya, diawal penciptaannya memang handphone hanya digunakan untuk berkomunikasi, namun semakin berkembang handphone tidak hanya digunakan untuk itu, tapi juga mengakses segala informasi apapun melalui media sosial yang dapat dipergunakan di handphone melalui jaringan internetnya. Masyarakat kita yang dulunya bersikap sosial dengan cara sering berkumpul, ngobrol, dan berbagi informasi melalui tatap muka, seakan sudah berganti dengan bersikap sosial dengan dilakukan dalam dunia maya. Semakin maju dan cepatnya pertumbuhan teknologi komunikasi ini berpengaruh dengan semakin banyaknya media sosial. Media sosial tidak hanya dipergunakan untuk saling menyapa orang lain di dalamnya, namun juga berbagai informasi melalui tulisan, gambar, vidio dan lain sebagainya. Banyak orang dengan mudah dan bebas membuat dan mencari segala bentuk informasi baik itu mengenai kesehatan, politik, agama, suku, dalam bentuk berita, vidio dan lainnya dimedia sosial. Tidak dapat dipungkiri bahwa pembuatan berita tersebut bertujuan untuk mendapatkan royalti dari iklan yang terdapat dalam berita yang viral. 
Kemudahan dan kebebasan mengeluarkan berita secara tidak langsung juga menyebabkan merebaknya berita hoaks dalam rangka membuat opini publik. Banyak kepentingan yang melatar belakangi orang pembuat berita hoaks baik itu untuk kepentingan pribadi atau kelompok demi mendapatkan royalti, menyerang atau memfitnah orang atau kelompok, ataupun untuk mengklaim suatu kelompok atau agama tertentu yang paling unggul diantara yang lain. Didalam penyebaran berita hoaks terdapat dua unsur pokok yakni yang pertama pembuat dan penerima, dan yang kedua adalah media yang dijadikan untuk menyebarkan dan menerima. Media tidak dapat berfungsi sendiri tanpa adanya manusia, jadi dari analisis tersebut manusia menjadi dasar atas adanya hoaks. Oleh sebab itu berita hoaks harus ditanggulangi dari manusianya.

Pada materi diktat filsafat manusia yang membedakan manusia dengan binatang adalah keberfikirannya, sehingga akan mendapatkan suatu kebenaran yang ada pada dirinya maupun selain dirinya. Didalam filsafat manusia, manusia dikatakan berupa dinamika atau yang punya dinamika. Dinamika berasal dari kata Yunani yang berarti dapat mampu. Dari kata ini dibentuk kata dinamit yang artinya kemampuan atau kekuatan. Maka kita nyatakan bahwa dinamika manusia atau manusia sebagai dinamika: tidak pernah berhenti, selalu dalam keaktifan. Keaktifan manusia dapat dilakukan baik saat sadar maupun tidak sadar, karena manusia sebagai rohani dan jasmani yang tidak dapat dipisahkan. Dalam kesadaran kita, kita selalu aktif, jadi selalu berupa dinamika yang aktif secara actual. Kita terus menerus menagkap, baik dengan indra maupun dengan budi. Demikian juga kita selalu menghendaki, selalu menerima ini dan itu.

Dinamika pada pribadi manusia dengan memandang manusia sebagai subjek. Manusia berdiri dengan pendirian, dengan sikap. Maka dengan itu manusia bisa merumuskan sikapnya, dapat menganalisa pendiriannya. Dengan demikian dalam kasus hoaks manusia dapat menentukan sikapnya dalam menanggapi berita bohong dengan tidak langsung mempercayainya, dalam hal ini masyarakat yang pada mulanya hanya menerima informasi, harus memulai dengan bersikap kritis terhadap berita yang diterimannya serta membentuk pendirian yang tidak mudah percaya. Baik perihal sumber informasi, maksud dari informasi yang disebarkan untuk 
kepentingan kelompok dengan memfitnah kelompok atau individu lain, maupun membuka aib dari seseorang maupun kelompok lain. Dan jangan masyarakat menerima sesuatu berdasarkan kesamaan suatu ras, suku ataupun agama, sehingga membuat kita langsung menerima informasi dengan mentah. Didalam filsafat, manusia adalah makhluk yang selalu berpikir untuk mencari kebenaran, kebenaran dapat dicari menggunakan akal. Dalam pembuatan berita menggunakan akal, maka dalam menganalisis suatu berita hoaks dapat menggunaakan kerangka berpikir untuk menyatakan suatu berita benar ataupun salah, sehingga sikap yang diambil akan mendapatkan kesimpulan yang benar atau salah mengenai berita tersebut. Dalam sudut pandang agama pun juga demikian, kita dianjurkan untuk tidak mempercayai suatu hal tanpa dilihat kebenarannya dulu, menyakiti sesama orang lain menggunakan fitnah sangat dilarang oleh agama. Bagaimana kita akan menghargai Tuhan jika kita tidak dapat saling menghargai atas sesama makhluk lainnya. lebih baik kita pertimbangkan terlebih dahulu apakah dengan kita menyebarkan berita hoaks terdapat sesorang maupun kelompok yang tersakiti olehnya. Berfilsafat mengajarkan kita untuk bepikir secara lebih dalam serta mempertimbangkan dampak dari berita hoaks itu sendiri. Menanggulangi berita hoaks tentunya dimulai dari diri kita sendiri. 


\section{KESIMPULAN}

Hoaks adalah usaha untuk menipu atau mengakali penerimannya, sehingga menggiring suatu opini tertentu serta mempercayainya. Hoaks muncul seiring dengan perkembangan teknologi, pengetahuan serta mudahnya mengakses sebuah informasi.

Berfilsafat merupakan upaya untuk mencari suatu kebenaran melalui pola pikir. Tidak mudah percaya akan suatu hal yang belum tentu kebenarannya termasuk sebuah informasi yang tersebar di media, namun senantiasa berpfikir kritis serta membangun sebuah pertanyaan apakah suatu informasi itu benar ataupun salah, tujuan dan maksud informasi tersebut untuk apa, apakah terdapat pernyataan yang provokatif, atau terdapatkah fitnah didalamnya. Sehingga kita dapat menentukan sikap untuk menanggapi suatu informasi yang didapat, lalu membentuk suatu pendirian untuk selalu menyebarkan kebaikan. 


\section{DAFTAR PUSTAKA}

Dewantara, A. W, Diktat Filsafat Manusia Tentang Intelek, Kehendak, Dan Dinamika Manusia.2019

DEWANTARA, AGUSTINUS WISNU. GOTONG-ROYONG MENURUT SOEKARNO DALAM PERSPEKTIF AKSIOLOGI MAX SCHELER, DAN SUMBANGANNYA BAGI NASIONALISME INDONESIA. Diss. Universitas Gadjah Mada, 2016.

Juliani, Reni. "Media Sosial Ramah Sosial V.S Hoaks". At-Tanzir: Jurnal Ilmiah Prodi Komunikasi Penyiaran Islam, [S.I], p. 136-149, dec. 2017. ISSN 2620-3359.

https://ejournal.staindirundeng.ac.id/index.php/tanzir/article/view/72

(Diakses Senin 1 juni 2019)

Rahadi, D. A. "Perilaku Pengguna Dan Informasi Hoax Di Media Sosial". Jurnal Manajemen dan Kewirausahaan Universitas Merdeka Malang. Vol.5, No. 1. 2017.

http://jurnal.unmer.ac.id/index.php/jmdk/article/view/1342/933

(Diakses Senin 1 Juni 2019)

https://www.kominfo.go.id/content/detail/8949/ini-cara-mengatasi-berita-hoax-didunia-maya-/0/sorotan_media (Diakses 1 Juni 2019) https://kominfo.go.id/content/detail/12008/ada-800000-situs-penyebar-hoax-diindonesia/0/sorotan_media (Diakses 1 Juni 2019) 